\title{
Grain Yield and Protein Content of Brazilian Cowpea Genotypes under Diverse Ugandan Environments
}

\author{
Gabriel Ddamulira1*, Carlos Antonio Fernandes Santos², Peter Obuo³, \\ Mildred Alanyo', Charles Kasozi Lwanga ${ }^{1}$ \\ ${ }^{1}$ National Crops Resource Research Institute, Kampala, Uganda \\ ${ }^{2}$ Embrapa Semi-Arid, Petrolina, Brazil \\ ${ }^{3}$ National Semi-Arid Resource Research Institute, Serere, Uganda \\ Email: ${ }^{*}$ ddamuliragab@yahoo.co.uk
}

Received 7 July 2015; accepted 21 August 2015; published 27 August 2015

Copyright (C) 2015 by authors and Scientific Research Publishing Inc.

This work is licensed under the Creative Commons Attribution International License (CC BY).

http://creativecommons.org/licenses/by/4.0/

(c) (7) Open Access

\begin{abstract}
Twenty nine cowpea genotypes, including four Ugandan genotypes, were evaluated for grain yield, protein stability and adaptability under diverse environments in a randomized complete block design with three replications. The analysis showed that cowpea grain yield and protein content were significantly $(P<0.01)$ affected by genotypes $(G)$, environments $(E)$, and interaction $(G \times E)$. Genotypes C2T and C2I had the highest grain yield and protein content respectively, but both were only adapted to specific environments. Genotypes C1J, C1V, C2A, C2O, and C2R were adapted to three environments with high yield which was stable. Similarly, genotypes BRS Pujante, C1J, C2Q and CIT also expressed high protein levels with high stability and wide adaptability. The study further revealed that Namulonge 2014B, Serere 2014A, Serere 2014B and Serere were the most favorable environments for obtaining high yield and protein respectively, because at these four environments, mean yield and protein were higher than the overall mean. All Brazilian genotypes had high protein levels compared to Ugandan genotypes indicating the potential of Brazilian genotypes in improving cowpea seed protein content in Uganda.
\end{abstract}

\section{Keywords}

Stability, Adaptability, AMMI, GxE Interaction

\footnotetext{
${ }^{*}$ Corresponding author.
}

How to cite this paper: Ddamulira, G., Santos, C.A.F., Peter Obuo, P., Alanyo, M. and Lwanga, C.K. (2015) Grain Yield and Protein Content of Brazilian Cowpea Genotypes under Diverse Ugandan Environments. American Journal of Plant Sciences, 6, 2074-2084. http://dx.doi.org/10.4236/ajps.2015.613208 


\section{Introduction}

Cowpea (Vigna unguiculata (L) Walp) is one of the most important legume crops grown in semi-arid tropical regions in Africa [1]. The crop is majorly produced in West Africa, with Nigeria as the leading producer and consumer of cowpea, accounting for $61 \%$ in Africa [2]. Uganda is also among the ten leading producers of cowpea and is ranked $8^{\text {th }}$ in Africa [3]. In Uganda, cowpea is ranked $4^{\text {th }}$ after beans, groundnuts, and soybean [3]. Cowpea is mostly grown in the drier eastern and northern parts of Uganda [4]. This is because the crop is tolerant to drought and adapted to warm weather, hence it can produce significant yield where other legumes like beans fail to grow [5].

Cowpea is also a famine staple crop and contributes greatly to food and nutrition security in semi-arid areas. In Uganda the average daily protein intake is estimated at $37.7 \mathrm{~g}$ per person day but it is much lower in eastern and northern drier areas [6]. Cowpea is high in protein and can produce more protein than the dominantly grown crops in semi-arid areas such as cassava, sweet potato and maize [7]. Unfortunately, the crop has often been considered as a subsistence crop receiving limited genetic improvement from mainstream research. This perception is, however, changing due to the increasing awareness of consumers, nutritionists and breeders of: i) the great genetic variation of nutritious protein in existing cowpea germplasm [1]; ii) the high protein content in cowpea bred lines [8]; and iii) the prevalence of protein malnutrition and its adverse effect on human health.

The levels and effects of malnutrition on human health are well documented [9]. Malnutrition among children and pregnant women is partly due to protein and micro-nutrient deficiencies [9]. Protein deficiency results into wasting, stuntedness, weight loss and lowers immunity to diseases, which increases health risks [10]. In Uganda, $40 \%$ of children below five years old are stunted and $6 \%$ wasted [11]. However, in developed countries, wasting and stuntedness has been reduced by use of fortified food supplements. In developing countries like Uganda, fortified foods have not reduced the effects of malnutrition and protein deficiencies due to their high cost of distribution and limited access by rural communities [12]. Staple foods enriched with protein through plant quality breeding need to be adopted as a complementary strategy to avert the effects of protein deficiency because this strategy provides a cheap source of proteins [13]. For instance, in semi-arid parts of Uganda where other protein-rich crops like beans and soybean cannot be grown, cowpea can be an equally nutritious substitute.

Accordingly, the national cowpea breeding program has developed and released high yielding cowpea varieties in Uganda, but they are low in protein content and some are not well adapted to dry conditions. In addition, over generations farmers have grown and selected landraces/cultivars that are well adapted, with preferred traits such as white color [14] but their yield and protein levels still remain low.

However, a number of high yielding cowpea lines with high protein content that are well adapted to semi-arid conditions have been developed in Brazil [8]. These genotypes could be adopted in Uganda to complement the existing varieties in improving the nutrition status of people living in the semi-arid areas of Uganda. Although these lines are well adapted to Brazil conditions, there is a need to understand their G x E interactions, adaptability and stability of their yield and protein content across diverse environments in Uganda. By understanding the $G \times \mathrm{E}$ interaction informed choices on their variety, potential and use in improving Ugandan cowpea germplasm will be made. Therefore, this study assessed the magnitude of $\mathrm{G}$ x E variation, adaptability and stability of Brazilian lines for grain yield and protein content across diverse environments.

\section{Materials and Methods}

\subsection{Genetic Materials}

Twenty nine cowpea genotypes were assessed in the study (Table 1). Twenty two of the Brazilian lines used in the study originated from a set of crosses involving three International Institute for Tropical Agriculture (IITA) accessions ("IT97K-1042-3", "IT99K-216-48-1", and "IT97K-499") which were high in protein and mineral content [15]. The lines were developed under semi-arid conditions in Brazil. BRS Tapaihum, BRS Pujante and BRS Carijo are released cowpea varieties in Brazil [8]. Checks (SECOW 2W, SECOW 5T, NE 19 and WC 36) were sourced from the National Cowpea Breeding Program (NCBP) at National Semi-Arid Research Institute (NaSARRI), Serere. SECOW 2W and SECOW 5T are released varieties that are ranked second to landraces in adoption in Uganda [16]. NE 19 and WC 36 are part of the cowpea germplasm collection held at NaSARRI which represents the landraces grown in northern and eastern Uganda, respectively. 
Table 1. Description of cowpea genotypes used in the study at Namulonge, Serere and Apac during the two seasons of 2014A and 2014B.

\begin{tabular}{|c|c|c|c|c|c|}
\hline Entry & Genotype ID & Genotype IPCA Code & Origin & Seed Colour & Days to Maturity of Cowpea in Uganda \\
\hline 1. & $\mathrm{C} 2 \mathrm{R}$ & G1 & Brazil & Black & $70-72$ \\
\hline 2. & C3S & G2 & Brazil & White & $76-81$ \\
\hline 3. & $\mathrm{C} 1 \mathrm{~N}$ & G3 & Brazil & Black & $72-75$ \\
\hline 4. & C1R & G4 & Brazil & Black & $72-74$ \\
\hline 5. & C2I & G5 & Brazil & Black & $70-73$ \\
\hline 6. & $\mathrm{C} 1 \mathrm{G}$ & G6 & Brazil & Black & $71-74$ \\
\hline 7. & C1S & G7 & Brazil & Black & $72-75$ \\
\hline 8. & $\mathrm{C} 1 \mathrm{M}$ & G8 & Brazil & Black & $73-76$ \\
\hline 9. & C2J & G9 & Brazil & Cream & $78-80$ \\
\hline 10. & $\mathrm{C} 2 \mathrm{C}$ & G10 & Brazil & Black & $74-77$ \\
\hline 11. & $\mathrm{C} 1 \mathrm{~J}$ & G11 & Brazil & White & $71-73$ \\
\hline 12. & $\mathrm{C} 1 \mathrm{~F}$ & G12 & Brazil & Black & $70-75$ \\
\hline 13. & CIT & G13 & Brazil & Black & $71-74$ \\
\hline 14. & $\mathrm{C} 2 \mathrm{O}$ & G14 & Brazil & Cream & $71-73$ \\
\hline 15. & $\mathrm{C} 2 \mathrm{~S}$ & G15 & Brazil & Cream & 73.83 \\
\hline 16. & $\mathrm{C} 2 \mathrm{~B}$ & G16 & Brazil & Black & $70-73$ \\
\hline 17. & $\mathrm{C} 2 \mathrm{~A}$ & G17 & Brazil & Black & $70-73$ \\
\hline 18. & C2Q & G18 & Brazil & Black & $72-76$ \\
\hline 19. & $\mathrm{C} 2 \mathrm{~T}$ & G19 & Brazil & Cream & $69-72$ \\
\hline 20. & $\mathrm{C} 1 \mathrm{O}$ & G20 & Brazil & Black & 72.78 \\
\hline 21 & C1I & G21 & Brazil & Black & $70-72$ \\
\hline 22. & C1V & G22 & Brazil & Black & $71-73$ \\
\hline 23. & BRS Tapiham & G23 & Brazil & Black & $73-77$ \\
\hline 24. & BRS Pujante & G24 & Brazil & Cream & $76-79$ \\
\hline 25. & BRS Carijo & G25 & Brazil & Black & $78-80$ \\
\hline 26. & SECOW 2W & G26 & Uganda & White & $72-76$ \\
\hline 27. & SECOW 5T & G27 & Uganda & Black & $71-75$ \\
\hline 28. & NE 19 & G28 & Uganda & Cream & $77-79$ \\
\hline 29. & WC 36 & G29 & Uganda & White & 73-78 \\
\hline
\end{tabular}

\subsection{Study Area}

The experiment was conducted in three locations (Namulonge, Apac and Serere). Namulonge represented central Uganda, where cowpea is grown as a leafy vegetable for the urban market [17]. Apac and Serere represented the mid northern and eastern respectively where cowpea is majorly grown in Uganda for grain (Ddungu et al., 2015). National Crops Resources Research Institute (NaCRRI) Namulonge, lies at an altitude of 1150 masl with a bimodal rainfall (1270 mm annually), annual mean temperature of $22.2^{\circ} \mathrm{C}$, with red sandy clay loam soils of $\mathrm{pH} 4.9$ - 5.0, covered by tropical rain forest type of vegetation. The second rain season at Namulonge is much higher and longer than the first rain season. Apac lies at an altitude of 1150 m.a.s.l with annual rainfall 975 $1000 \mathrm{~mm}$, annual temperature ranging between $17^{\circ} \mathrm{C}$ and $29^{\circ} \mathrm{C}$, with reddish brown clay loam of pH $5.4-5.9$ and covered with savanna vegetation type. National Semi-Arid Crops Resources Research Institute (NaSARRI), 
Serere lies at altitude (1140 m.a.s.l), and characterized by a low rainfall (900 - $1000 \mathrm{~mm}$ annually), annual temperature of $26^{\circ} \mathrm{C}$ with sandy loam soils [18] of pH 5.2 - 6.0 and covered with tall savannah vegetation. In additional, both Apac and Serere have a bimodal rainfall pattern but with short second season rains

\subsection{Experiment Design and Cultural Practices}

At all sites cowpea was planted during the first rains (March/June, 2014A) in 2014 and during the second rains (October/November, 2014 B) of the same year. The experiment was laid out in randomized complete block design with three replications. In Apac the experiment was hosted on one of farmer's field but the replication and plot size were the same as those at the two on-station sites. Each cowpea genotype was planted at a spacing of $50 \times 20 \mathrm{~cm}$ in $2 \times 2 \mathrm{~m}$ plots. Two seedlings were planted per hill and $2-3$ weeks later the seedlings were thinned to one plant per hill. To protect the plants from insect pests and diseases, dimethoate (40\% EC at a rate of 1.0 litre $\cdot \mathrm{ha}^{-1}$ ) and antracol at the same rate was applied at budding, flowering and podding as recommended [19] The fields were maintained weed free by hand hoeing three times before flowering to avoid flower abortion.

\subsection{Data Collection}

At physiological maturity when at least $50 \%$ of the pods presented a characteristic green discoloration total yield for each genotype was determined. Ten cowpea plants were randomly harvested from two central rows in $1 \times 1 \mathrm{~m}$ area in each experiment unit. The harvested plants were threshed, the seed was weighted and moisture content determined. The moisture was corrected to $13 \%$ and seed weight recorded. The seed weight data was then extrapolated to per plot and per hectare basis.

\subsection{Protein Analysis}

The Micro-Kjeldhal method was used to quantity the protein content within the dry cowpea seed of each genotype. Five millimeters of digestion solution was added to $100 \mathrm{mg}$ dry cowpea seeds of a given genotype. The digestion of each sample took place in a digester block with a gradual increase in temperature to $370^{\circ} \mathrm{C}$ to completely fix the protein nitrogen into ammonia, in the form of ammonium sulphate. The nitrogen was then distilled and removed in the form of ammonia in $2 \%$ boric acid, forming borate ions that were titred with standard sulphuric acid to quantify the protein nitrogen, and later conversion to total protein content. The results were expressed in percentage protein, with an adjustment to dry weight. The total proteins were analyzed in the food science laboratory at Makerere University Kampala, Uganda. Total protein quantification analyses using the Micro-Kjeldhal method were carried out following the previously reported methods [20] [21].

\subsection{Data Analysis}

Analysis of variance was performed initially for each of the three sites to determine the performance of genotypes. A combined analysis over locations and seasons was conducted to elucidate the performance of different genotypes across environments. To determine the adaptability of genotypes to different environments, $\mathrm{G} \times \mathrm{E}$ analysis was performed using the Additive Main Effects and Multiplicative Interaction (AMMI) model [22]. The AMMI model was used because it is more effective in determining the most stable and high yielding genotypes in multi-environmental trials compared to earlier procedures [23] [24]. The model uses the analysis of variance (ANOVA) approach to study the main effects of the genotype and environments and a Principal Component Analysis (PCA) for the residual multiplicative interaction between genotypes and environments [25].

\section{Results and Discussions}

\subsection{Identifying High Yielding Cowpea Genotypes}

The results from analysis of variance for grain yield exhibited significant $(P<0.001)$ differences among genotypes, environments and the interaction ( $\mathrm{G}$ x E) (Table 2). Among genotypes, C2T produced the highest grain yield while C3S gave the least grain yield (Table 3). The high grain yield obtained from genotype C2T implied that the performance of this genotype was better than the Ugandan cowpea genotypes across all tested environments. The superior yield of C2T was more evident in Apac where it was the only genotype that yielded above 
Table 2. ANOVA for yield and protein content for cowpea genotypes grown at three environments in seasons 2014A and 2014B in Uganda.

\begin{tabular}{ccccc}
\hline & \multicolumn{2}{c}{ Grain Yield } & \multicolumn{2}{c}{ Protein Content } \\
\hline Source & DF & MS & DF & MS \\
\hline Genotype & 28 & $0.5745^{* * *}$ & 28 & $190.0180^{* * *}$ \\
Environment & 2 & $31.2886^{* * *}$ & 2 & $54.1108^{* * *}$ \\
Genotype x Environment & 56 & $0.4423^{* * *}$ & 56 & $8.9032^{* * *}$ \\
Error & 348 & 0.1925 & 172 & 0.1673 \\
\hline
\end{tabular}

${ }^{* * *}$ Significant at $0.01, \mathrm{DF}=$ degrees of freedom, MS = mean squares.

Table 3. Grain yield ( $\left.\mathrm{t} \cdot \mathrm{ha}^{-1}\right)$ and protein content (\%) of cowpea genotypes grown at three environments in Uganda during seasons 2014A and 2014B.

\begin{tabular}{|c|c|c|c|c|c|c|c|c|}
\hline \multirow[t]{2}{*}{ Genotype } & \multicolumn{2}{|c|}{ Namulonge } & \multicolumn{2}{|c|}{ Apac } & \multicolumn{2}{|c|}{ Serere } & \multirow{2}{*}{$\begin{array}{l}\text { Mean } \\
\text { Grain } \\
\text { Yield }\end{array}$} & \multirow{2}{*}{$\begin{array}{c}\text { Mean } \\
\text { Protein } \\
\text { Content }\end{array}$} \\
\hline & Yield & Protein & Yield & Protein & Yield & Protein & & \\
\hline $\mathrm{C} 2 \mathrm{R}$ & 1.10 & 27.1 & 0.66 & 30.9 & 1.29 & 26.8 & 1.02 & 28.3 \\
\hline C3S & 0.54 & 27.4 & 0.35 & 30.2 & 0.96 & 25.3 & 0.62 & 27.6 \\
\hline $\mathrm{C} 1 \mathrm{~N}$ & 0.57 & 26.1 & 0.63 & 29.9 & 1.25 & 23.0 & 0.82 & 26.4 \\
\hline C1R & 0.56 & 26.5 & 0.67 & 26.9 & 1.48 & 24.5 & 0.90 & 26.4 \\
\hline C2I & 0.98 & 29.7 & 0.39 & 30.7 & 1.47 & 30.5 & 0.94 & 30.3 \\
\hline C1G & 1.38 & 29.3 & 0.62 & 26.5 & 1.43 & 24.3 & 1.15 & 26.7 \\
\hline C1S & 0.67 & 28.6 & 0.37 & 26.0 & 1.81 & 29.0 & 0.95 & 27.9 \\
\hline $\mathrm{C} 1 \mathrm{M}$ & 1.04 & 26.8 & 0.63 & 27.7 & 1.46 & 24.7 & 1.05 & 26.4 \\
\hline $\mathrm{C} 2 \mathrm{~J}$ & 0.67 & 27.1 & 0.27 & 24.8 & 1.49 & 29.3 & 0.81 & 27.1 \\
\hline $\mathrm{C} 2 \mathrm{C}$ & 0.90 & 28.8 & 0.70 & 29.6 & 1.27 & 25.4 & 0.97 & 27.9 \\
\hline $\mathrm{C} 1 \mathrm{~J}$ & 0.85 & 28.3 & 0.66 & 26.6 & 2.02 & 26.8 & 1.17 & 27.3 \\
\hline $\mathrm{C} 1 \mathrm{~F}$ & 0.95 & 30.0 & 0.53 & 25.9 & 1.41 & 32.7 & 0.97 & 29.5 \\
\hline $\mathrm{C} 1 \mathrm{~T}$ & 1.30 & 30.0 & 0.45 & 27.6 & 1.35 & 25.0 & 1.03 & 27.5 \\
\hline $\mathrm{C} 2 \mathrm{O}$ & 1.33 & 27.1 & 0.44 & 25.3 & 1.28 & 24.7 & 1.02 & 25.7 \\
\hline $\mathrm{C} 2 \mathrm{~S}$ & 0.82 & 29.0 & 0.47 & 24.8 & 1.27 & 26.0 & 0.85 & 26.6 \\
\hline $\mathrm{C} 2 \mathrm{~B}$ & 1.75 & 29.1 & 0.48 & 27.4 & 1.13 & 23.5 & 1.12 & 26.7 \\
\hline $\mathrm{C} 2 \mathrm{~A}$ & 1.06 & 28.3 & 0.41 & 25.0 & 1.68 & 25.4 & 1.05 & 26.2 \\
\hline $\mathrm{C} 2 \mathrm{Q}$ & 1.04 & 27.6 & 0.40 & 28.2 & 1.48 & 26.6 & 0.97 & 27.5 \\
\hline $\mathrm{C} 2 \mathrm{~T}$ & 1.12 & 27.8 & 1.43 & 24.8 & 2.15 & 25.1 & 1.56 & 25.9 \\
\hline $\mathrm{C} 1 \mathrm{O}$ & 0.95 & 26.6 & 0.59 & 26.4 & 1.27 & 28.9 & 0.94 & 27.3 \\
\hline C1I & 1.26 & 28.1 & 0.67 & 25.2 & 1.08 & 25.1 & 1.00 & 26.1 \\
\hline $\mathrm{C} 1 \mathrm{~V}$ & 0.83 & 25.9 & 0.46 & 27.5 & 1.98 & 24.2 & 1.09 & 25.9 \\
\hline BRS Tapaihum & 0.92 & 26.4 & 0.69 & 25.4 & 1.41 & 25.7 & 1.01 & 25.8 \\
\hline BRS Pujante & 0.36 & 28.0 & 0.52 & 28.0 & 1.24 & 28.1 & 0.71 & 28.0 \\
\hline BRS Carijo & 0.16 & 25.9 & 0.90 & 24.8 & 1.32 & 25.0 & 0.79 & 25.2 \\
\hline NE 19 & 0.83 & 25.7 & 0.58 & 24.1 & 0.82 & 25.4 & 0.74 & 25.1 \\
\hline WC 36 & 0.83 & 24.4 & 0.49 & 24.8 & 1.16 & 22.5 & 0.83 & 23.9 \\
\hline SECOW 2W & 0.90 & 26.5 & 0.78 & 25.2 & 1.63 & 22.5 & 1.10 & 24.7 \\
\hline SECOW 5T & 1.04 & 24.3 & 0.64 & 23.1 & 1.71 & 24.6 & 1.13 & 24.0 \\
\hline Mean & 0.92 & 27.5 & 0.58 & 26.7 & 1.42 & 25.9 & & \\
\hline $\mathbf{L S D}_{0.05}$ & 0.46 & 0.64 & 0.47 & 0.72 & 0.56 & 0.64 & & \\
\hline
\end{tabular}


Table 4. AMMI ANOVA of grain yield and protein content for 29 cowpea genotypes in six environments (three locations and two seasons) during 2014A and 2014B in Uganda.

\begin{tabular}{|c|c|c|c|c|c|c|}
\hline \multirow[b]{2}{*}{ Source } & \multicolumn{3}{|c|}{ Grain Yield } & \multicolumn{3}{|c|}{ Protein Content } \\
\hline & DF & SS & MS & DF & SS & MS \\
\hline Treatments & 173 & 152.90 & $0.884^{* * *}$ & 86 & 1139.3 & $13.25^{* * *}$ \\
\hline Genotype & 28 & 16.31 & $0.583^{* * *}$ & 28 & 530.8 & $18.96^{* * *}$ \\
\hline Environment & 5 & 64.92 & $12.983^{* * *}$ & 2 & 108.2 & $54.11^{* * *}$ \\
\hline Genotype x Environment & 140 & 71.67 & $0.512^{* * *}$ & 56 & 500.3 & $8.93^{* * *}$ \\
\hline PCA1 & 32 & 27.38 & $0.856^{* * *}$ & 29 & 367.1 & $12.66^{* * *}$ \\
\hline Residuals & 108 & 44.29 & $0.410^{* * *}$ & 27 & 133.2 & $4.93^{* * *}$ \\
\hline Error & 336 & 29.30 & 0.087 & 168 & 28.0 & 0.17 \\
\hline
\end{tabular}

*** significant at $0.01, \mathrm{MS}=$ mean square, $\mathrm{DF}=$ Degrees of freedom and $\mathrm{SS}=$ sums of squares

the national average yield $\left(0.93 \mathrm{t} \cdot \mathrm{ha}^{-1}\right)$ for cowpea in Uganda [4]. The better performance of C2T in terms of yield was probably due to its early maturity. Because of its earliness to mature, the critical stages of its development (flowering and pod formation) which require sufficient moisture occurred during the rainy season. Ref [26] reported that reproductive development, yield potential and seed formation in cowpea are enhanced by moisture availability during flowering and pod formation stages.

\subsection{Identifying Suitable Environments for Cowpea Genotypes.}

Across the diverse environments tested, cowpea yield was significantly $(P>0.05)$ different. In environments E2 (Namulonge 2014B), E5 (Serere 2014A) and E6 (Serere 2014B), mean yields were above the overall mean (0.97 $\mathrm{t} \cdot \mathrm{ha}^{-1}$ ), indicating that these environments were favorable for obtaining high cowpea grain yield. The high yield obtained at Namulonge 2014B was explained by the rainfall pattern that occurred in this area compared to two other environments where the experiments were conducted. Namulonge has a bimodal rainfall pattern with much longer second season rains. The rain was received during cowpea germination, vegetative and reproductive stage, yet sufficient soil moisture during the reproductive stage is known to enhance grain filling which result into increased grain yield [27]. On the other hand, soil texture differentiated environments Serere 2014A and 2014B from the rest. The sandy loamy soil in Serere is suitable for proper and health cowpea growth because it does not restrict root development, has good aeration and drainage [28] [29]. The ideal soil type in Serere explained why in this particular environment better cowpea yield was obtained compared to other environments which had different soil types.

\subsection{Combined Analysis of Variance for Grain Yield}

The AMMI analysis for the grain yield indicated that G x E interaction effects was highly significant $(P<0.01)$ and partitioned in the first principal component axis (IPCA). The IPCA1 explained $17.6 \%$ of the interaction sums (Table 4). This implied that the interaction of cowpea genotypes with six environments was predicted by the first component of genotypes and environment which was in agreement with the recommendation by [26]. However, this contradicted the findings by [30] which recommended that the most accurate model for AMMI can be predicted using the first two IPCAs. These results indicate that the number of terms to be included in an AMMI model cannot be specified prior without first trying AMMI predictive assessment [31]. In general, factors like type of crop, diversity of the germplasm and range of environmental conditions will affect the degree of complexity of the best predictive model [32].

\subsection{Grain Yield Stability}

The analysis of the biplot indicated that genotypes: C2T (G19), C1J (G11), C1M (G8), SECOW 5T (G26), SECOW-2W (G27), C2B (16), C1G (G6), C1T (G13), C2O (G14), C2A (G17), C2Q (G18), C2R(G1), C1V (G22), BRS Tapaihum (G23), C1I (G21) and C1F (G12) were high yielding since AMMI placed them at the right hand side of the midpoint of the axis representing the overall mean of $0.97 \mathrm{t}^{\mathrm{h}} \mathrm{ha}^{-1}$ on the biplot (Figure 1). 


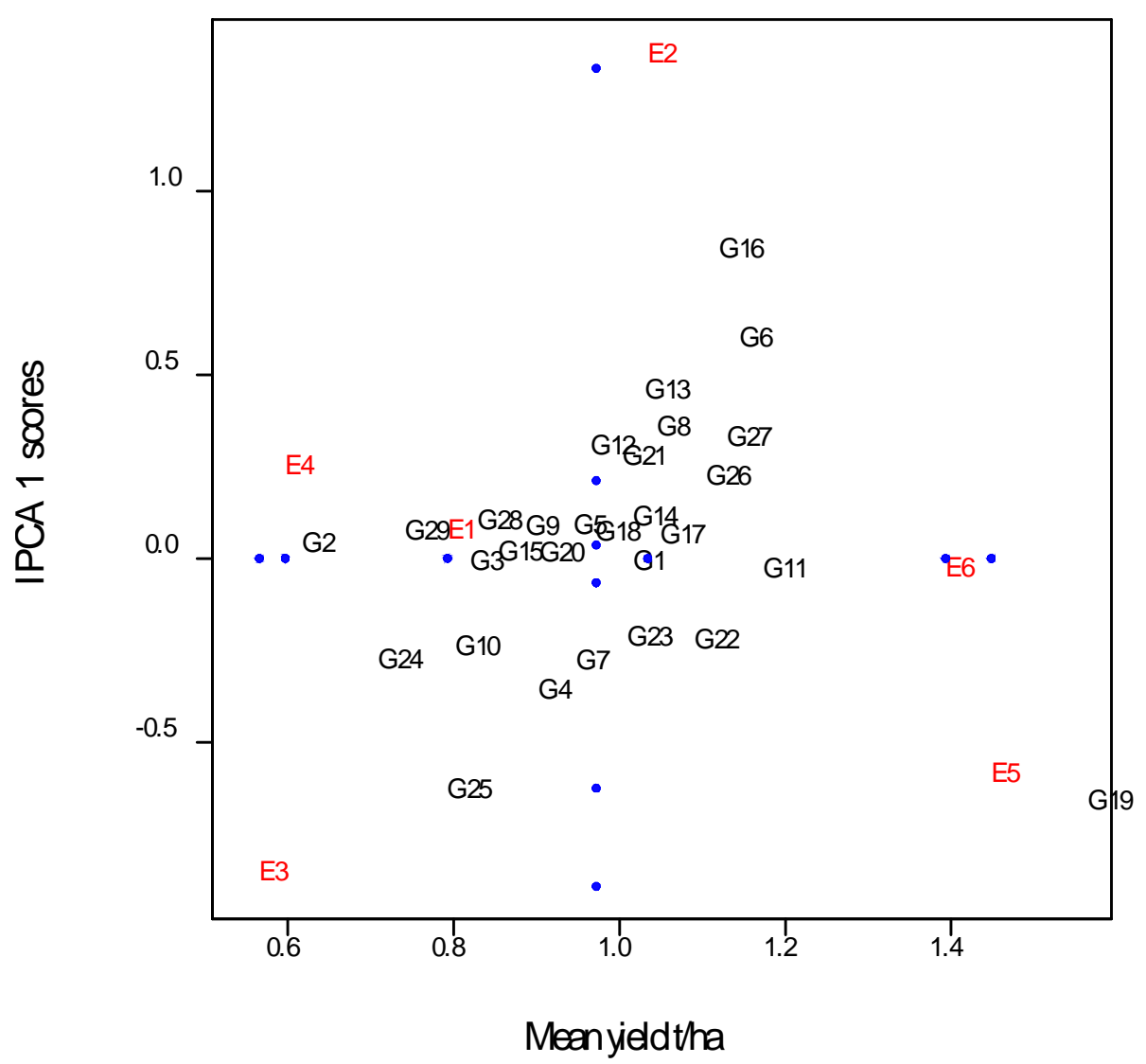

Figure 1. AMMI 1 Biplot for grain yield $\left(\mathrm{t} \cdot \mathrm{ha}^{-1}\right)$ of 29 cowpea genotypes $(\mathrm{G})$ and six environments (E) using genotypic and environmental score. Environments E1 = (Namulonge, season 2014A), E2 = (Namulonge, Season 2014B), E3 = (Apac, Season 2014A), E4 = (Apac, Season 2014B), E5 = (Serere, Season 2014A $)$ and E6 = (Serere, Season 2014B).

In contrast genotype; BRS Carijo (G25), BRS Punjante (G24), C1R (G4), C1N (G3),C3S (G2) C2S (G15), C1O (G20) and C2J (G9) were low yielding given that they were placed at the left hand side of the midpoint of the axis on the biplot. Even though C2T had high yield but it was only adapted to specific environments i.e Serere (E5) and (E6), because according to AMMI model, genotypes with high mean performance and large value of IPCA score are considered to be adapted to specific environments. The specific adaptability to certain environments possibly explained the low grain yield of C2T reported by [8] in Brazil. It is presumed that although in certain environments C2T yielded highly, in other environments like Brazil, the same genotype might be less adapted due to limited ability to mobilize growth resources in certain environments which reduce on its ability to produce dry matter and grain yield. Genotype C1J was equally high yielding and more stable than C2T under Ugandan conditions. This indicated that although both were high yielding, C1J was a better genotype to adopt in Uganda because it was adapted in all environments tested.

\subsection{Identifying Cowpea with High Protein Content}

Analysis of variance indicated significant $(P<0.01)$ differences in protein levels of cowpea genotypes and environments (Table 2). Cowpea genotypes, C2I had the highest protein content while protein levels in WC 36 were the lowest (Table 3). Previous studies done in Nigeria and Zambia indicate that cowpea seed protein content ranges from $21 \%$ - 30\% [33] [34].

More recent author [35] has reported cowpea lines with protein content as high as $34 \%$. The study results were highly consistent with that of [30] since in this study seed protein content ranged between $23.9 \%$ and $30.9 \%$. Similarly, genotype C2I which had the highest protein content (30.9\%) under Ugandan conditions contained approximately the same protein level (29.9\%) as previously reported by [8] in Brazil. On the contrary, 
genotype C2R which had the highest protein levels (34\%) in Brazil contained 4\% less protein under Ugandan conditions, which might have been due to differences in environmental factors. In the present study all Brazilian genotypes had high protein compared to the Ugandan genotypes (check). Hence, the breeding program in Uganda can use genotype C2I to improve upon the seed protein content of Ugandan cowpea varieties up to $30 \%$. Such a strategy can improve the nutritional levels of communities in cowpea growing areas and also provide protein raw materials for agro-processing.

\subsection{Identifying Stable Environments for Cowpea Protein Content}

In identifying favorable environments for growing high protein cowpea genotypes, the AMMI biplot exhibited that the three environments differed significantly (Figure 2). Environment E2 (Namulonge) had small contribution to the variation, but environments E1 (Serere) and E3 (Apac) contributed mostly to the variability. The variability was mainly attributed to differences in soil type and weather conditions in the different environments. Although a study by [36] indicated that protein content of cowpea did not differ among soil types in the different environments, but findings by [37] showed that cowpea crude protein differed by sites due to difference in soil type and weather conditions. In line with the previous findings, the present study also exhibited significant differences in protein content under different environments arising from variation in soil type and weather conditions.

Stability was most observed in environment E2 and the average protein content of genotypes grown in this environment was above the overall mean making it the most favorable environment for growing high protein cowpea genotypes. The stability of protein content in genotypes grown at Serere (E2) implied that this environment had favorable conditions for obtaining high protein levels. This was explained by soil texture at Serere. Among the study sites, it was only Serere with sandy loam soils and according to [38] cowpea performed best

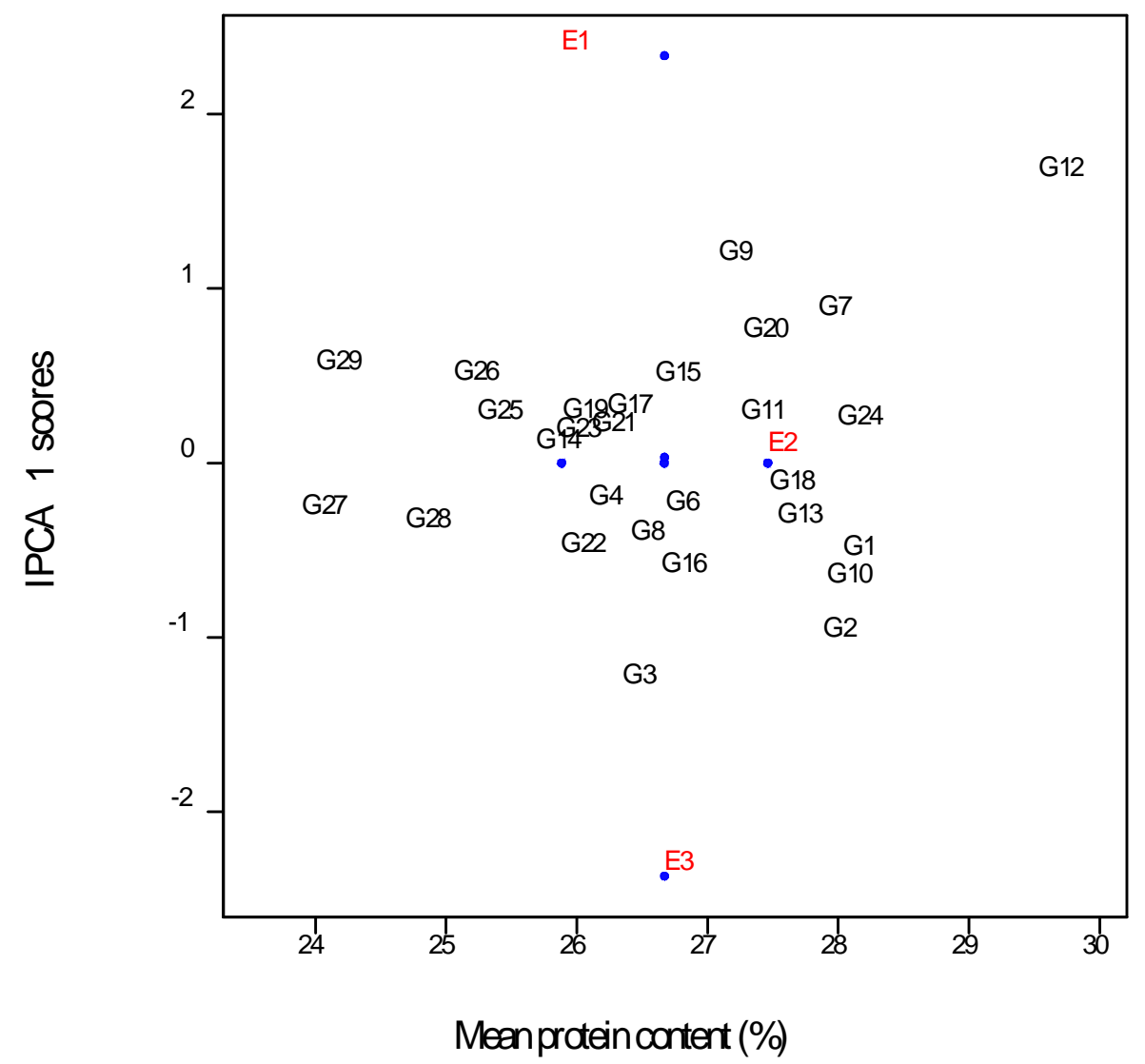

Figure 2. AMMI Biplot for protein content (\%) of 29 cowpea genotype (G) and three environments (E) using genotypic and environmental scores. Environments; E1 = Serere, E2 = Namulonge and E3 = Apac. 
on well drained sandy loam or sandy soil where $\mathrm{pH}$ was in the range of 5.5 to 6.5 . In addition, Serere with less rain compared to other sites, it had more dry seasons. Ref [39] reported that more protein was attainable during the dry season than in the rainy season, which probably explained the stability and high protein levels observed in cowpea genotype grown at Serere compared to other sites that received more rainfall like Namulonge. Since the same site had the highest cowpea grain yield it could be considered as the most favorable environment for production of high yielding and protein-rich cowpea varieties in Uganda. This suggestion is in agreement with [40] who recommended that breeders should aim at developing varieties that are stable in more than one trait within the same environment. Basing on Figure 2, protein levels in genotypes: C20, C1R, C1G, C2Q, BRS Tapaihum, C1I, C1J, CIT and BRS Pujante were observed to have greater stability. In terms of protein levels, most genotypes including the checks were moderately stable, except C1N, C2J and C1F which were unstable though relatively high in protein content. On the other hand, genotypes C1J, C2Q and BRS Pujante had the highest protein content and stability compared to the check which were widely grown in Uganda.

\subsection{G × E Interaction Analysis for Protein Content}

ANOVA indicated that a $\mathrm{G} \times \mathrm{E}$ interaction was highly significant $(P<0.01)$ for protein content (Table 4). AMMI analysis was continued further to estimate $\mathrm{G} \times \mathrm{E}$ for protein content which exhibited significant interactions in the pooled analysis. The AMMI ANOVA showed that genotype, environment and $\mathrm{G} x \mathrm{E}$ were significant $(P<0.01)$. The $\mathrm{G} \times \mathrm{E}$ interaction, genotype and environment accounted for $43.9 \%, 49.6 \%$ and $9.5 \%$ of the sums of squares respectively (Table 4). The effect of each genotype and environment on protein content was illustrated by AMMI (IPCA vs means) biplot (Figure 2). The values closer to the origin of the axis (IPCA1) provided a smaller contribution to the interaction than those that were far away.

\section{Conclusion}

The study was conducted to understand the yield and protein performance of Brazilian cowpea genotypes under diverse environments in Uganda. The grain yield and protein content varied based on the genotypes, environments and their interactions. Although genotype C2T had the highest yield but it was only adapted to specific environments. Hence genotype C1J, which was equally high yielding, stable and adapted to the three environments tested, should be recommended for cultivation in Uganda. In terms of environments, the best grain yield was obtained from Serere, which implied that this environment was favorable for growing Brazilian lines in Uganda. The interaction of genotype $x$ environment also affected grain yield which implied that, the grain yield of cowpea differed based on different environmental factors (soil types and rainfall). Although, genotype C21 had the highest protein levels, it might not be the best genotype to grow as a high protein cowpea genotype in Uganda. This is because it is only adapted to specific environment, i.e. Serere. But genotypes such as C1J, C2Q and BRS Pujante which are high in protein and are adapted to three environments with high stability can be promoted in Uganda for human and animal consumption. However, we recommend that in the future the high protein content in C21 can be used by breeding program to improve protein content in Ugandan cowpea germplasm.

\section{Acknowledgements}

The research was supported by a grant from Africa-Brazil Agricultural Innovation Marketplaces and Embrapa. The authors are grateful to National Crops Resources Research Institute (NaCRRI), National Semi-arid Crops Research Institute for hosting the research and Embrapa Semi-Arid Petrolina for providing cowpea germplasm for the study

\section{References}

[1] Afiukwa, C.A., Ubi, B.E., Kunert, K.J., Titus, E.J. and Akusu, J.O. (2013) Seed Protein Content Variation in Cowpea Genotypes. World Journal of Agricultural Sciences, 1, 094-099.

[2] FAOSTAT (Food and Agriculture Organisation of the United Nations) (2013) Statistics Division 2013. http://faostat3.fao.org/faostat-gateway/go/to/download/Q/QC/E

[3] Ronner, E. and Giller, K.E. (2012) Back Ground Information on Agronomy, Farming Systems and On-Going Projects on Grain Legumes in Uganda, 17-18. www.N2Africa.org 
[4] Dungu, S.P., Ekere, W., Bisikwa, J., Kawooya, R., Kalule, O. and Biruma, M. (2015) Marketing and Market Integration of Cowpea in Uganda. Journal of Development and Agricultural Economics, 7, 1-11.

[5] Bisikwa, J., Kawooya. R., Ssebuliba, J.M., Ddungu, S.P., Biruma, M. and Okello, D.K. (2014) Effects of Plant Density on the Performance of Local and Elite Cowpea Varieties in Eastern Uganda. African Journal of Applied Agricultural Sciences and Technologies, 1, 28-41.

[6] de Jager, I. (2013) Literature Study: Nutritional Benefits of Legume Consumption at Household Level in Rural Areas of Sub-Saharan Africa, 95. www.N2Africa.org

[7] Ssewanya, S. and Kasirye, I. (2010) Food Insecurity in Uganda: A Dilemma to Achieving the Hunger Millennium Development Goal. Economic Policy Centre Report.

[8] Santos, C.A.F. and Boiteux, L.S. (2013) Breeding Biofortified Cowpea Lines for Semi-Arid Tropical Areas by Combining Higher Seed Protein and Mineral Levels. Genetics and Molecular Research, 12, 6782-6789. http://dx.doi.org/10.4238/2013.December.16.4

[9] Bain, L.E., Awah, P.K., Geraldine, N., Kindong, N.P., Sigal, Y., Bernard, N. and Tanjeko, A.T. (2013) Malnutrition in Sub-Saharan Africa: Burden, Causes and Prospects. The Pan African Medical Journal, 15, 120.

[10] Stephenson, K., Amhor, R., Mallowa, S., Nungo, R., Maziya-Dixon, B., Gichuki, S., Mbanaso, A. and Manary, M. (2010) Consuming Cassava as a Staple Food Places Children 2-5 Years Old at Risk for Inadequate Protein Intake, an Observational Study in Kenya and Nigeria. Nutritional Journal, 9, 1-9. http://dx.doi.org/10.1186/1475-2891-9-9

[11] Uganda Bureau of Statistics (UBOS) and ICF International Inc. (2012) Uganda Demographic and Health Survey 2011. UBOS, Kampala and ICF International Inc., Calverton. http://www.measuredhs.com/publications/publication-fr264-dhs-final-reports.cfm

[12] Costa, G., Queiroz-Monici, K., Reis, S. and Oliveira, A. (2006) Chemical Composition, Dietary Fibre and Resistant Starch Contents of Raw and Cooked Pea, Common Bean, Chickpea and Lentil Legumes. Food Chemistry, 94, 327-330. http://dx.doi.org/10.1016/j.foodchem.2004.11.020

[13] Phillips, R.D., Mcwatters, K.H., Chinannan, M.S., Hung, Y.C., Beuchatm, L.R., Sefa-Dedeh, S., et al. (2003) Utilization of Cowpeas for Human Food. Field Crops Research, 82, 193-213. http://dx.doi.org/10.1016/S0378-4290(03)00038-8

[14] Mundua, J. (2010) Estimation of Consumer Preferences for Cowpea Varieties in Kumi and Soroti Districts, Uganda. MSc. Thesis, Makerere University, Kampala, 81.

[15] Singh, B.B. (2007) Recent Progress in Cowpea Genetics and Breeding. Acta Horticulturae, 752, 69-75. http://dx.doi.org/10.17660/actahortic.2007.752.7

[16] ASTI (2015) A Consolidated Database of Crop Varietal Releases, Adoption, and Research Capacity in Africa South of the Sahara. http://www.asti.cgiar.org/diiva/uganda/cowpeas

[17] Ssekabembe, C.K. (2008) Effect of Proportion of Component Species on the Productivity of Solanum aethiopicum and Amaranthus lividus under Intercropping. African Journal of Agricultural Research, 3, 510-519.

[18] Selvaradjou, S.K., Montanarella, L., Spaargaren, O. and Dent, D. (2005) European Digital Archive of Soil Maps (EuDASM)—Soil Maps of Africa EUR 21657 EN, 2005. http://eusoils.jrc.ec.europa.eu/esdb_archive/EuDASM/Africa/lists/cug.htm

[19] Karungi, J., Adipala, E., Ogenga-Latigo, M.W., Kyamanya, S., Oyobo, N. and Jackai, L.E.N. (2000) Pest Management in Cowpea. Part 2. Integrating Planting Time, Planting Density and Insect Application for Management Cowpea Field Insect Pests in Eastern Uganda. Crop Protection, 19, 237-245. http://dx.doi.org/10.1016/S0261-2194(00)00014-4

[20] Giami, S.Y. (2005) Compositional and Nutritional Properties of Selected Newly Developed Lines of Cowpea (Vigna unguiculata L. Walp). Journal of Food Composition and Analysis, 18, 665-673. http://dx.doi.org/10.1016/j.jfca.2004.06.007

[21] Frota, K.M.G., Soares, R.A.M. and Arêas, J.A.G. (2008) Chemical Composition of Cowpea (Vigna unguiculata L. Walp), BRS-Milênio Cultivar. Ciencia e Tecnologia de Alimentos, 28, 470-476. http://dx.doi.org/10.1590/S0101-20612008000200031

[22] Gauch, H.G. (1993) MATMODEL Version 2.0 AMMI and Related Analysis for Two Way Data Matrices. Micro Computer Power. Ithaca, New York, 59.

[23] Finlay, K.W. and Wilkinson, G.N. (1963) The Analysis of Adaptation in Plant Breeding Programme. Australian Journal of Agricultural Research, 14, 742-754. http://dx.doi.org/10.1071/AR9630742

[24] Eberthart, S.A. and Russel, W.A. (1966) Stability Parameters for Comparing Varieties. Crop Science, 6, 36-40. http://dx.doi.org/10.2135/cropsci1966.0011183X000600010011x

[25] Egesi, C.N.R. and Asiedu, R. (2002) Analysis of Yam Yields Using the Additive Main Effects and Multiplicative Inte- 
ractions (AMMI) Model. African Crop Science Journal, 10, 195-201.

[26] Asio, M.T., Osiru, D.S.O. and Adipala, E. (2005) Multilocational Evaluation of Selected Local and Improved Cowpea Lines in Uganda. African Crop Science Journal, 13, 239-247.

[27] Faisal, E.A. and Abdel, S.H.S. (2010) Effect of Water Stress Applied at Different Stages of Growth on Seed Yield and Stages of Growth on Seed Yield and Water Use Efficiency of Cowpea. Agriculture and Biology Journal of North America, 1, 534-540.

[28] Ecocrop (2009) Ecocrop Database, FAO. http://ecocrop.fao.org/ecocrop/srv/en/home

[29] Directorate Agricultural Information Services (DAIS) (2011) Production Guidelines for Cowpea. www.daff.gov.za

[30] Gauch, H.G. and Zobel, R.W. (1996) AMMI Analysis of Yield Trials. In: Kang, M.S. and Gauch, H.G., Eds., Genotype-by-Environment Interaction, CRC Press, Boca Raton, 85-122. http://dx.doi.org/10.1201/9781420049374.ch4

[31] Kaya, Y., Palta, C. and Taner, S. (2002) Additive Main Effects and Multiplicative Interactions Analysis of Yield Performance in Bread Wheat Genotypes across Environments. Turuk Journal of Agriculture, 26, 275-279.

[32] Crossa, J., Gauch, H.G.J. and Zobel, R.W. (1990) Additive Main Effects and Multiplicative Interaction Analysis of Two International Maize Cultivar Trials. Crop Science, 30, 493-500. http://dx.doi.org/10.2135/cropsci1990.0011183X003000030003x

[33] Mwasaru, M.A., Muhammad, K., Bakar, J. and Cheman, Y.B. (1999) Effect of Isolation Technique and Conditions on the Extractability, Physiochemical and Functional Properties of Pigeon Pea (Cajanus cajan) and Cowpea (Vigna unguiculata) Protein Isolates. II. Functional Properties. Food Chemistry, 67, 445-452. http://dx.doi.org/10.1016/S0308-8146(99)00151-X

[34] Ajeigbe, H.A., Ihedioha, D. and Chikoye, D. (2008) Variation in Physico-Chemical Properties of Seed of Selected Improved Varieties of Cowpeas as It Relates to Industrial Utilization of the Crop. African Journal of Biotechnology, 7, 3642-3647.

[35] Santos, C.A.F., Costa, D.C.C., da Silva W.R. and Boiteux, L.S. (2012) Genetic Analysis of Total Seed Protein Content in Two Cowpea Crosses. Crop Science, 52, 2501-2506. http://dx.doi.org/10.2135/cropsci2011.12.0632

[36] Lauriault, L.M., Angadi, S.V. and Marsalis, M.A. (2011) Soil Type Affected Cowpea Forage Nutritive Value. Forage and Grazinglands, 9.

[37] Sebetha, E.T., Modi, A.T. and Owoeye, L.G. (2015) Cowpea Crude Protein as Affected by Cropping System, Site and Nitrogen Fertilization. Journal of Agricultural Sciences, 7, 9752-9760.

[38] Lim, T.K. (2012) Edible Medicinal and Non-Medicinal Plants. Springer, the Netherlands, 371-380. http://dx.doi.org/10.1007/978-94-007-4053-2_45

[39] Mukhtar, F.B., Mohammed, M. and Ajiegbe, H.A. (2010) Effect of Farmyard Manure on Senescence, Nitrogen and Protein Levels in Leaves and Grains of Some Cowpea Varieties. Bayero Journal of Pure and Applied Sciences, 3, 9699. http://dx.doi.org/10.4314/bajopas.v3i1.58726

[40] Nkhoma, N. (2013) Stability of Yield and Antioxidant Content of Selected Advanced Cowpea (Vigna unguiculata [L] Walp.) Mutation Derived Lines. MSc. Thesis, University of Zambia, Lusaka. 